\title{
Natural nest-sites of Great Tits (Parus major) in a primeval temperate forest (Białowieża National Park, Poland)
}

\author{
Marta Maziarz • Tomasz Wesołowski • \\ Grzegorz Hebda $\cdot$ Marta Cholewa
}

Received: 21 September 2014/Revised: 23 December 2014/ Accepted: 26 January 2015/Published online: 11 February 2015

(C) The Author(s) 2015. This article is published with open access at Springerlink.com

\begin{abstract}
Knowledge of the breeding ecology of the Great Tit Parus major is vast, but almost exclusively concerns birds using nest-boxes. Information on birds nesting in natural conditions is scant. Here, we present the results of the first thorough study on natural nest-sites of the Great Tit. The data, including descriptions of nestcavity location and dimensions, were collected during 39 breeding seasons in the primeval forest of Białowieża National Park (BNP), Poland. With an excess of available tree-cavities providing a diverse choice of nesting options, Great Tits nested mainly in non-excavated, very deep and spacious cavities with elongated, narrow openings, placed at intermediate heights in living tree trunks. Different sets of tree species were used in different habitats. The pattern of nest-site utilisation by Great Tits in BNP overlapped with that recorded in other areas, but showed niche separation from other non-excavating hole-breeders in BNP. This indicates that Great Tits have core nest-site preferences, which have probably evolved in response to selective forces such as, e.g., risk of predation, flooding, sufficient nest illumination and/or efficient air ventilation.
\end{abstract}

Communicated by F. Bairlein.

Electronic supplementary material The online version of this article (doi:10.1007/s10336-015-1169-6) contains supplementary material, which is available to authorized users.

M. Maziarz $(\bowtie) \cdot$ T. Wesołowski · M. Cholewa Laboratory of Forest Biology, Wrocław University,

Sienkiewicza 21, 50335 Wrocław, Poland

e-mail: martamaz@biol.uni.wroc.pl

G. Hebda

Department of Biosystematics, Opole University,

Oleska 22, 45052 Opole, Poland
Keywords Parus major - Tree cavities · Nest placement . Cavity dimensions $\cdot$ Primeval conditions

\section{Zusammenfassung}

Natürliche Nistplätze der Kohlmeise in einem Urwald (Białowieża Nationalpark, Polen)

Das Wissen über die Brutökologie der Kohlmeise (Parus major) ist sehr groß, bezieht sich aber fast ausschließlich auf Vögel, die in Nistkästen brüten. Informationen über Vögel, die unter natürlichen Bedingungen brüten, sind rar. Hier stellen wir die Ergebnisse der ersten umfassenden Untersuchung vor, die sich mit natürlichen Nistplätzen der Kohlmeise beschäftigte. Die Daten, darunter Beschreibungen der Lage und Dimension der Nisthöhlen, wurden während 39 Brutzeiten im Urwald des Białowieża Nationalparks (BNP) in Polen gesammelt. Bei einem Überschuss an verfügbaren Baumhöhlen, der eine vielfältige Auswahl von Nistmöglichkeiten zur Verfügung stellte, brüteten die Kohlmeisen hauptsächlich in natürlichen, sehr tiefen und geräumigen Höhlen mit länglichen, schmalen Öffnungen, in mittlerer Höhe von Stämmen lebender Bäume. In unterschiedlichen Habitaten wurden andere Baumarten gewählt. Das Muster der Nistplatzwahl der Kohlmeisen im BNP überlappte mit dem in anderen Gebieten aufgezeichneten, zeigte aber eine Nischentrennung von anderen Höhlenbrütern, die in natürlichen Höhlen brüteten. Das zeigt, dass Kohlmeisen grundlegende Nistplatzpräferenzen haben, die sich wahrscheinlich als Antwort auf einen Selektionsdruck entwickelt haben, wie zum Beispiel Prädationsrisiko, Überschwemmungsgefahr, ausreichende Ausleuchtung der Bruthöhle und/oder Ventilation. 


\section{Introduction}

The Great Tit Parus major is a small (ca. $20 \mathrm{~g}$ ) nonexcavating, cavity-nesting passerine of Eurasian forests and various wooded habitats, which depends on pre-existing tree cavities for nest-sites (Glutz von Blotzheim and Bauer 1993). Despite a widespread and substantial transformation of Europe's woodlands, resulting in an impoverishment of tree cavities in many situations (reviewed in Newton 1998), the Great Tit remains one of the commonest bird species in such habitats (Glutz von Blotzheim and Bauer 1993). Great Tits show a large degree of plasticity in nest-site choice: in modified habitats, they nest in holes in trees, walls or the ground, in rock crevices, litter containers, wine barrels, pipes, and, where cavities are absent, in the open nests of other bird species, e.g. European Jay Garrulus glandarius, Eurasian Magpie Pica pica, or Common Blackbird Turdus merula (reviewed in Glutz von Blotzheim and Bauer 1993; Monrós et al. 1999). Nestboxes often attract Great Tits, in which they often breed at high densities, several times higher than in natural conditions (Glutz von Blotzheim and Bauer 1993; Mänd et al. 2005; Wesołowski 2007a). As a result, the Great Tit has become one of the most intensively studied bird species in Europe (1,807 papers up to 2010; Lambrechts et al. 2010). But, although the knowledge of the Great Tit's breeding ecology is vast (monographs: e.g. Gibb 1950; Kluijver 1951; van Balen 1973; Gosler 1993), it is based almost exclusively on nest-box observations, and studies of the birds breeding in natural cavities are very rare. Information on the natural nest-sites of Great Tits can be extracted from only a few papers (Edington and Edington 1972; Booij 1977; van Balen et al. 1982; Nilsson 1984; East and Perrins 1988; Wesołowski 1989; Sandström 1992; Carlson et al. 1998; Bai et al. 2005; Remm et al. 2006; Camprodon et al. 2008; Morozov 2009). These studies are mostly based on limited samples (many involving $<40$ holes), and none provides a complete description of the natural nest-sites of Great Tits, with a full characterisation of cavity location and cavity dimensions.

In previous observations of Great Tits and other nonexcavating cavity-nesting species, it was shown that the pattern of nest cavity utilisation may be affected by limited access to tree cavities, leading to inter- and intra-specific competition for nest-sites (e.g. Perrins 1979; van Balen et al. 1982; Nilsson 1984). Therefore, to obtain an unbiased picture of nest-site selection under natural conditions, it is necessary to observe the behaviour of birds in unmodified environments (e.g. Lack 1965; Tomiałojć et al. 1984; Wesołowski 2007b). Such conditions have survived in the strictly protected primeval forest within the Białowieża National Park (hereafter BNP), eastern Poland, which is a remnant of the lowland forests that once covered large parts of temperate Europe. Here, tree cavities are diverse and superabundant, differing in hole origin (excavated/nonexcavated), location (limb/trunk, tree species of various size), state of wood decay, height above ground (from ground level to the tops of crowns), and internal dimensions. Such diversity of tree cavities offers a wide spectrum of nesting options for non-excavating hole-breeders (reviewed in Wesołowski 2007b); the birds can freely choose their most suitable nest-sites (review in Walankiewicz 1991; Wesołowski 2007b), and inter- or intra-specific competition is unimportant (e.g. Tomiałojć et al. 1984; Walankiewicz and Mitrus 1997; Wesołowski 2003). Previous studies in BNP have described the natural nest-sites of several non-excavating cavity-nesting birds, including Marsh Tit Poecile palustris (Wesołowski 1996), Nuthatch Sitta europaea (Wesołowski and Rowiński 2004), Pied Ficedula hypoleuca and Collared Flycatchers $F$. albicollis (Czeszczewik and Walankiewicz 2003; Walankiewicz et al. 2007) and Blue Tit Cyanistes caeruleus (Wesołowski and Rowiński 2012). A preliminary work on Great Tits by Wesołowski (1989) included a description of nest cavity location in a tree (no cavity measurements were made), indicating that Great Tits preferred to nest in non-excavated cavities with vertical slit-like openings, located in living trunks of hornbeams (in oak-lime-hornbeam habitat) or alders (in riverine stands). However, the number of nests (37 in 2 types of habitats) was limited. This study aims to provide a comprehensive information on nest-site selection by Great Tits, and allows for further comparisons of differences in cavity usage between different non-excavating hole-breeders living under the same natural conditions.

In this paper, we present long-term data (collected over 39 years) on natural nest-sites of Great Tits breeding in three main habitat types within the primeval forest: oaklime-hornbeam, riverine and mixed-coniferous stands. We discuss the nest-cavity utilisation of Great Tits in comparison to the pattern observed in other studies, and also that recorded for other non-excavating cavity-nesting species in BNP. We consider the general adaptive function of nest-site choice of Great Tits.

\section{Methods}

Study area

Białowieża forest is a vast (ca. $\left.1,500 \mathrm{~km}^{2}\right)$ and continuous forest, situated in the middle of the European plain, at the Polish-Belarusian border (co-ordinates of Białowieża village, $52^{\circ} 41^{\prime} \mathrm{N}, 23^{\circ} 52^{\prime} \mathrm{E}$ ). Its western part (ca. $45 \%$ of the area) lies inside Poland. The majority of tree stands are under management, but a $47.5-\mathrm{km}^{2}$ block of the best- 
preserved primeval old-growth stands has been exempt within the strictly protected part of the BNP. The protected old-growth stands are multi-storeyed, mixed-species and uneven-aged, with a canopy formed by trees over 200 years old (Tomiałojć and Wesołowski 2004). The tallest Norway spruces Picea abies reach over $50 \mathrm{~m}$, and the other tree species from $35 \mathrm{~m}$ (common hornbeam Carpinus betulus, birch Betula spp.) to $45 \mathrm{~m}$ (pedunculate oak Quercus robur, common ash Fraxinus excelsior). The girth at breast height of the thickest trees ranges from $410 \mathrm{~cm}$ (Norway maple Acer platanoides and aspen Populus tremula) to $740 \mathrm{~cm}$ (oak; Niechoda and Korbel 2011). The stands contain a large amount of standing dead timber and fallen trees (20-25\% of total wood volume; Bobiec 2002).

Most of the BNP consists of three distinct types of oldgrowth stands:

- oak-lime-hornbeam Tilio-Carpinetum (covering $44 \%$ of BNP) - the richest in tree species and structurally the most diverse habitat, composed mostly of hornbeam, small-leaved lime (Tilia cordata), oak, spruce, and maple, with small amounts of ash, elm (Ulmus spp.), birch and aspen. The understory is sparse, formed mostly by common hazel (Corylus avellana);

- riverine ash-alder Circaeo-Alnetum, Carici elongataeAlnetum (22\% of BNP)—swampy, open canopy deciduous forest with abundant dead wood, dominated by black alder Alnus glutinosa, common ash and Norway spruce, with admixture of birch;

- coniferous Peucedano-Pinetum (28\% of BNP)mixed-coniferous, comprising mainly Norway spruce and Scots pine Pinus sylvestris with fewer deciduous trees: birch, oak and aspen.

For detailed description and photographs of the stands, see, e.g., Tomiałojć et al. (1984), Wesołowski et al. (2006, 2010).

\section{Locating nests}

The Great Tit nest cavities were located during study periods varying in intensity of observations. In 1975-2007 and 2012-2013, the nests were found during mapping census work done in study plots established in 1975, in three main habitats: oak-lime-hornbeam (plots $\mathrm{C}, \mathrm{M}$ and $\mathrm{W}$ ), riverine ( $\mathrm{K}$ and $\mathrm{L}$ ), and mixed-coniferous (NW and $\mathrm{NE}$ ). The total area of plots varied from 187.5 ha in 1980-2011 to 358.1 ha in 1977. All study plots were permanently marked, and situated $1-3 \mathrm{~km}$ apart (details given in Tomiałojć et al. 1984; Wesołowski et al. 2006, 2010). Additionally, some nests were found during a regular survey of tree cavity inspection performed since 1993 in the same study plots, three in oak-lime-hornbeam $(\mathrm{C}, \mathrm{M}, \mathrm{W})$ and one in riverine forest $(\mathrm{K}$; the total area ca. 260 ha; details in Wesołowski 2001, 2011, 2012). About one-third of the nest cavities (34 \%) found in 1975-2013 were located during an intensive study period in 2008-2011 in oak-lime-hornbeam plots C (48 ha) and M (54 ha). During this period, some further nests in the remaining study plots were also found in the course of continuous bird census and cavity inspection work (see above). Single holes which were located outside the study areas, in other parts of BNP, were also included. Nest-boxes were not available in the forest.

To establish the number of breeding pairs during the intensive study period (2008-2011), attempts were made to mark as many Great Tits as possible in plots $\mathrm{C}$ and $\mathrm{M}$ with a unique combination of three colour rings and one individually numbered aluminium ring. Catching was undertaken just prior to nest-building, using mist-nets, playback and a dummy bird at point locations distributed 150-200 m apart, across both entire study plots, to incorporate all breeding territories. This method enabled the marking of at least one of the birds in most of the breeding pairs in the plots (55-62\% of males and 7-14\% of females in different seasons). Because mostly new (unringed) birds were found on the plots each year, the catching was repeated every spring. All ringed and unringed birds were subsequently followed by six well-trained observers during daily visits to study plots, to map the birds' movements and territorial behaviour (such as boundary disputes and singing), with special attention given to females collecting and carrying nest material to tree cavities. This allowed us to judge the number of breeding pairs on plots and assess the number of nests to be found. In total, during the intensive study period, we succeeded in finding the nests of nearly all (an estimated $97 \%$ ) pairs breeding in plots $\mathrm{C}$ and $\mathrm{M}$.

\section{Description of nest-cavities}

During the intensive (2008-2011) and non-intensive study periods (1975-2007 and 2012-2013), the same variables of nest-cavity location were noted, i.e. tree species, height of entrance from the ground level (measured to the nearest $1 \mathrm{~m}$ with a clinometer for holes situated higher than $10 \mathrm{~m}$, and visually estimated for those below), and entrance orientation to the nearest $1 / 8$ of the compass. Other characteristics recorded from 1980 were: trunk girth at breast height, hole type (woodpecker excavated vs. non-excavated), location on the tree (trunk vs. limb/branch), state of walls (live vs. dead), cavity entrance inclination (vertical, upward-facing, or under a sloping trunk/limb), shape of the entrance (rounded vs. fissure), and presence of 'knotholes' (conical bulge formed at site of a previous limb break).

The nest-cavity measurements were taken mainly in 2008-2011. Only $19 \%$ (317 cavities) of data on cavity 
dimensions were collected in the remaining years (1995 and 2005-2007 exclusively). Due to safety and technical reasons, cavities in very thick trees or in snags were measured less often than in other situations. Measurements were taken directly after the young had fledged, using a collapsible ruler and a flexible torch. They included: entrance diameter (least and greatest dimension of the cavity opening, taken in a vertical or horizontal plane), cavity diameter (least and greatest dimension of the cavity's horizontal cross-section, taken at the level of the top of nest material, usually in a plane perpendicular to the entrance axis), nest distance from the entrance (vertical distance between lower edge of the entrance and the top of nest material), cavity depth (vertical distance between lower edge of the entrance and the cavity bottom after the nest was removed), 'safety distance' (distance between the bottom edge of the external wall of the entrance and the centre of the nest at the rim level, indicating how far a predator would have to reach to remove eggs or nestlings), and girth of trunk at the entrance height (in 'knotholes' measured below or just above the protuberance).

Tree-species composition and size (girth at breast height) was recorded in 2008 in oak-lime-hornbeam study plots $\mathrm{C}$ and $\mathrm{M}$. All living and dead trees with girth at breast height $\geq 53 \mathrm{~cm}$ (the thinnest tree occupied by Great Tits) were recorded and measured within 10-m-radius plots around breeding cavities used by Great Tits in 2008 and at grid points spaced $150 \mathrm{~m}$ apart across the study plots. The radius plots never overlapped.

\section{Data analysis}

The analyses include previous data of Great Tit cavity location in a tree (27 nests in oak-lime-hornbeams and 10 nests in riverine stands), collected in 1975-1986 during the preliminary study in BNP (Wesołowski 1989).

During the whole study (1975-2013), $30 \%$ of 459 cavities were re-used by Great Tits in a subsequent year. However, during the intensive observations in plots $\mathrm{C}$ and $M$ in 2008-2011, when most cavity location and measurements were recorded, only $19 \%$ of 196 cavities were used more than once, and always by different birds in each year. As a cavity's attributes changed in subsequent years due to growth or decay of the substrate (e.g. Wesołowski 1995), and no two sets of measurements for a reused hole were the same, every sample involved a different (independent) combination of the bird's choice and cavity properties. Therefore, we considered that the risk of pseudo-replication could be disregarded. Moreover, considering only unique cavity locations would not reflect the complete cavity usage by the breeding population, as this would discount the birds' choice of those occupying 'reused' cavities.
The data for variables collected during the intensive and non-intensive study periods yielded similar results and, therefore, we pooled them. The exception was the girth of nest trees and the height of nest cavities above the ground-parameters which were apparently underestimated during the non-intensive study years (1975-2007 and 2012-2013). In these years, much less effort was put into finding Great Tit cavities, so the samples likely included fewer nests which were harder to detect, i.e. situated higher in larger trees. In contrast, during the intensive study period of 2008-2011 observers strived to find all first breeding attempts on the survey plots, providing complete information on cavity height and the size distribution of nest trees. Therefore, we decided to present the nest-tree girth and the hole height values solely from the intensive study period (2008-2011, plots C and M).

Sample sizes of variables differ between individual analyses, because collecting a full set of measurements was not possible in every case.

For statistical calculations we used non-parametric tests, following formulae in Statistica 10.0 (StatSoft 2011). All probability values shown are two-tailed.

\section{Results}

\section{Cavity location}

In BNP, each pair of Great Tits had access to several tree cavities they could choose from, as indicated by the number of cavities used in 2011 compared with the cumulative number of cavities used in the full four seasons of the intensive study ( 23 of 86 in plot $C$, and 37 of 110 in plot M). Although the number of usable cavities in our study area could be overestimated by $6-21 \%$ (Wesołowski 2001), each Great Tit female could apparently still choose from at least 2-4 cavities. These are conservative estimates (Wesołowski 2007a), as the number of usable cavities never used by Great Tits is unknown.

Great Tits bred mostly in the deciduous stands of BNP (mean densities were similar in oak-lime-hornbeam and ash-alder habitats, ca. 3-5 pairs/10 ha), and less commonly in mixed-coniferous stands (mean density ca. 1-2.5 pairs/10 ha; Wesołowski et al. 2006, 2010). In 1975-2013, only 11 nests were found in mixed-coniferous forest: eight in pine, two in birch and one in poplar. In the riverine stands, nest cavities were placed almost exclusively in alder (77 \%) and ash (21\%), while in oak-limehornbeam stands mainly in hornbeam and lime (84\%; Online Resource 1). In the latter habitat, Great Tits occupied cavities in hornbeam more frequently than the proportion of this tree species in the forest would indicate, and proportionately less often in lime (Online Resource 2). The 
birds clearly avoided nesting in spruce in oak-lime-hornbeam stands (Online Resource 2) and other types of habitat. Despite spruce being one of the dominant species in riverine and mixed-coniferous stands (Wesołowski et al. 2006), no nests were located in this tree species in both habitats (Online Resource 1, see also above).

Great Tit breeding cavities were proportionally more often located in thicker trees when comparing the girth size frequency distribution of the trees in the forest (Fig. 1; $\left.\chi^{2}=63.1, d f=8, P<0.001\right)$. In 2008-2011, the girth at breast height of nest trees ranged from 53 to $538 \mathrm{~cm}$, with an average of $169 \mathrm{~cm}$ (SD 76.2) in plots $C$ and M. Girth of nest trees varied among tree species (Kruskal-Wallis ANOVA, $\left.H_{5,250}=54.6, P<0.001\right)$; aspen, spruce, and birch (classified together as 'other' species) were the thinnest, and maple, ash and oak the thickest (Online Resource 3$)$.

In 2008-2011, Great Tit nest cavities were situated from 0.3 to $28 \mathrm{~m}$ above ground level, at an average $8.9 \mathrm{~m}$ (SD 6.3) in plots $C$ and $M$. The height depended on tree species: holes were placed the lowest in hornbeam, and the highest in maple, oak, and ash (Online Resource 3; Kruskal-Wallis ANOVA, $\left.H_{5,255}=54.1, P<0.001\right)$. The majority of Great Tit nests ( $77 \%, n=255)$ were located up to $12 \mathrm{~m}$ above ground (Fig. 2). The height of holes increased with the girth at breast height of all trees $\left(r_{\mathrm{S}}=0.61, P<0.001\right.$, $n=250$ ), which was also evident for individual tree species except ash $\left(r_{\mathrm{S}}=0.41-0.94, P<0.03\right)$.

The compass orientation of all nest cavities was uniformly distributed among eight divisions $\left(\chi^{2}=2.0\right.$, $d f=7, P=0.96, n=742$ ), from $11 \%$ facing south-east and north-west to $16 \%$ facing north.

The majority of cavity entrances $(69 \%, n=614)$ were in a vertical plane, $25 \%$ directed upwards and only $6 \%$ facing downward from the horizontal. Among 152 cavities

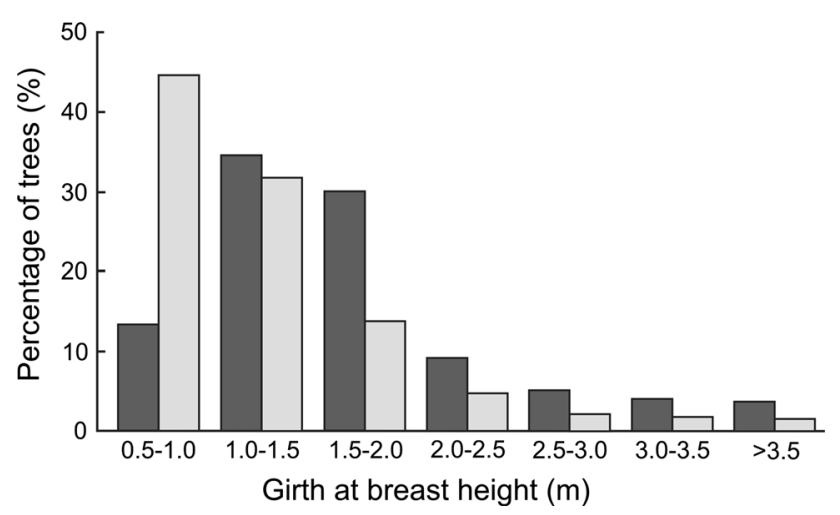

Fig. 1 Percentage of trees containing Great Tit Parus major nestcavities (dark grey; $n=249$ ) and of available trees with girth at breast height $\geq 53 \mathrm{~cm}$ (corresponding to the thinnest Great Tit nest tree; light grey; $n=913$ ) in girth size classes during 2008-2011 in two plots $(\mathrm{C}$ and $\mathrm{M})$ with an upward-facing entrance, 15 were located in a fork of the trunk (see Fig. 3 for example). The proportion of cavities with a vertical or upward-facing entrance varied between tree species; an upward inclination of openings was more frequent in ash, lime and maple, and vertical mainly in alder (Online Resource 4).

The majority of Great Tit nest-holes were slit-shaped $(67 \%)$, or 'knotholes' (26\%). The slits most often occurred in alder and hornbeam, and knotholes in ash and maple (Online Resource 4).

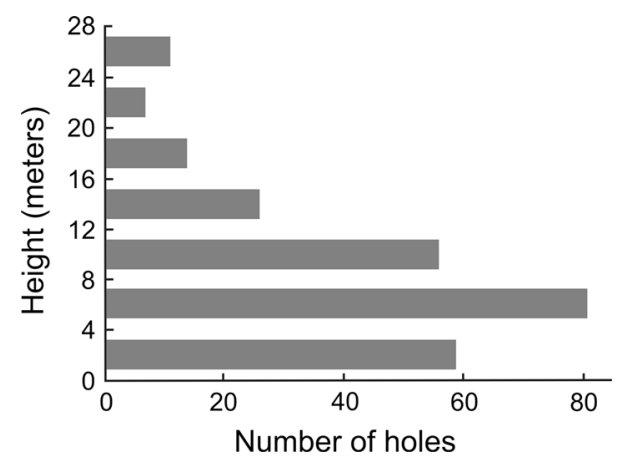

Fig. 2 Distribution of the height of Great Tit nest-holes above the ground in 2008-2011 in two plots (C and M; $n=255$ cavities)

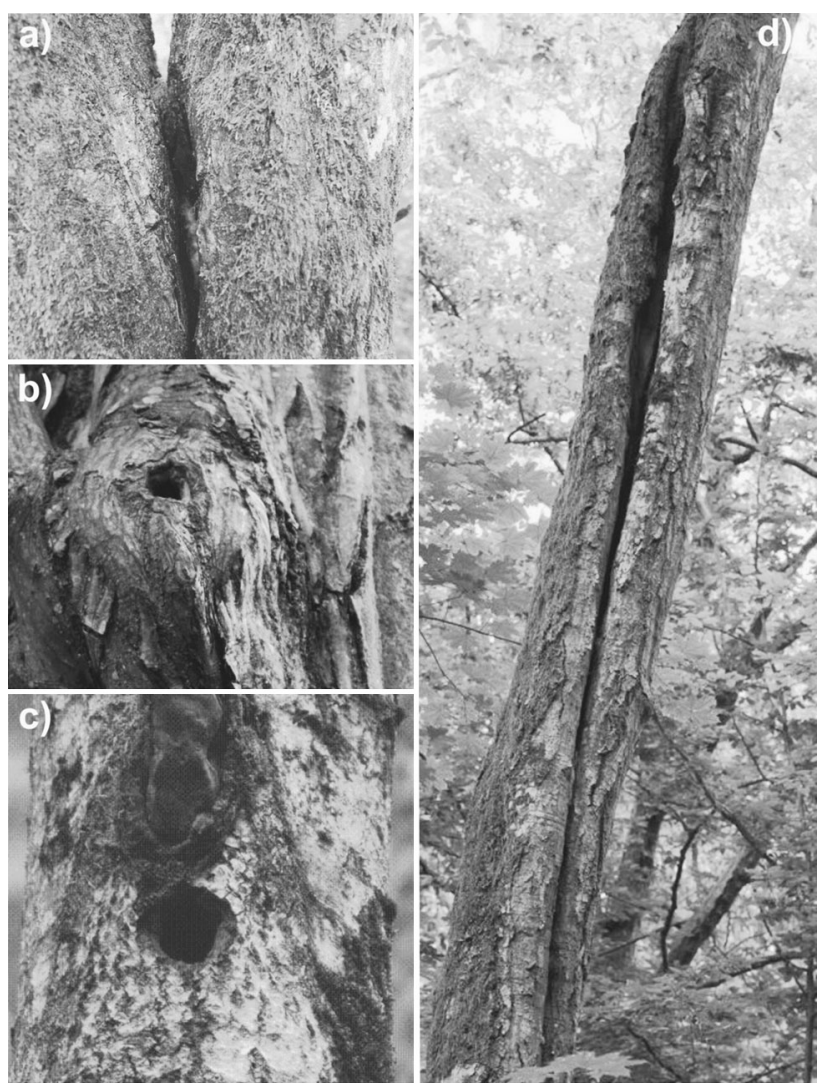

Fig. 3 Examples of Great Tit breeding holes: trunk fork (a), 'knothole' (b), woodpecker-made (c), elongated slit (d) 
Woodpecker-made cavities are abundant in BNP. They are annually excavated by eight woodpecker species, mainly in dead wood, and are available to Great Tits for several years thereafter (reviewed in Wesołowski 2007b, 2011). Despite this, only $6 \%(n=699)$ of Great Tit nests were located in woodpecker cavities, with almost onefifth of them (7/43) being in dead wood. Overall, only $5 \%(n=713)$ of Great Tit breeding cavities were situated in dead wood (Online Resource 5). Woodpeckermade cavities occupied by the tits were most often in aspen, oak, alder and 'other' species (pine, spruce, elm and birch); for each tree species, excavated cavities comprised 23-63\% of nests (Online Resource 5). Only cavities in oak and 'other' species (all pine plus one birch) were found to occur more frequently in dead wood (Online Resource 5).

Great Tits bred in cavities located mainly in tree trunks, with only $14 \%$ being in tree limbs (Online Resource 5). The nests in limbs were absent in aspen, rare in alder and hornbeam, but common in ash, oak and maple (Online Resource 5). In 2008-2011, in plots C and M, limb cavities were recorded mainly in thicker trees (median girth at breast height $215 \mathrm{~cm}, n=58$ ) compared to trunk cavities (median $143 \mathrm{~cm}, n=189$; Mann-Whitney test, $Z=7.1$, $P<0.001)$. They were also higher above the ground (median $14.0 \mathrm{~m}, n=59$ ) than cavities in trunks (median $6 \mathrm{~m}, n=191$; Mann-Whitney test, $Z=9.3, P<0.001$ ).

\section{Cavity dimensions}

Great Tits most often used nest-holes with elongated entrances, which were typical of non-excavated cavities (for an example, see Fig. 3). The greatest diameter of the entrance was most frequently two (48\% of nests), three (16\%), or four $(10 \%)$ times longer than the least diameter. More elongated entrances, up to 11 times longer than wide, were rare. Cavities with rounded openings comprised only
$6 \%$ of the 308 measured holes. Occasionally, the shape of the entrance was triangular (10 cases) or irregular (5).

The least diameter of the entrance ranged from 2 to $14.5 \mathrm{~cm}$ (median $3.2 \mathrm{~cm}$ ) and the greatest diameter from 2.5 to $23 \mathrm{~cm}$ (median $7 \mathrm{~cm}$; Table 1), while the entrance area varied from 4.9 to $119.3 \mathrm{~cm}^{2}$ (median $20.3 \mathrm{~cm}^{2}$ ). The least diameter of the entrance increased with height above ground $\left(r_{\mathrm{S}}=0.25, P<0.001, n=312\right)$, and the greatest diameter decreased $\left(r_{\mathrm{S}}=-0.33, P<0.001, n=308\right)$, so openings of cavities located higher above ground tended to be smaller and more rounded than those situated lower. Other cavity dimensions did not change with height (Spearman correlations, $r_{\mathrm{S}}<0.08, P>0.18$ ).

The least diameter of the cavity bottom ranged from 5 to $40 \mathrm{~cm}$ (median $14 \mathrm{~cm}$; Table 1) and the greatest diameter from 9 to $45 \mathrm{~cm}$ (median $17 \mathrm{~cm}$ ). Cavity bottoms were usually circular $(78 \%, n=234)$ or slightly elongated (15\%), and only $7 \%$ of cavities were more than twice as long than wide. Infrequently the cavity-bottom was triangular (6 cases), pear-shaped (3), irregular (3), two-chambered (2), star-shaped (1), or rhomboid (1). The maximum bottom area was 30 times larger than the smallest (respectively 1,256 and $39 \mathrm{~cm}^{2}$ ), although in $78 \%$ of cavities it was smaller than $300 \mathrm{~cm}^{2}$ (median $184 \mathrm{~cm}^{2}$; Table 1). More spacious cavities were recorded in thicker trunks/ limbs $\left(r_{\mathrm{S}}=0.45, P<0.001, n=288\right)$. The median girth of trunk or limb at the entrance height was $126 \mathrm{~cm}$ (from 53 to $350 \mathrm{~cm}, n=300)$.

Cavity depth, measured after the nest was removed, ranged from 3 to $109 \mathrm{~cm}$ (median $30 \mathrm{~cm}$; Table 1). Great Tits could adjust the nest distance from the entrance by moderating the nest material filling the cavity, primarily moss (Glutz von Blotzheim and Bauer 1993). Nest thickness increased with cavity depth $\left(r_{\mathrm{S}}=0.62, P<0.001\right.$, $n=169$ ), though the nest distance from the opening was still greater in deeper cavities $\left(r_{\mathrm{S}}=0.76, P<0.001\right.$, $n=169$ ), with a median of $19 \mathrm{~cm}$ and range of $0-67 \mathrm{~cm}$
Table 1 Dimensions of Great Tit Parus major nest-cavities in 1995-2011 in Białowieża National Park

\footnotetext{
${ }^{\mathrm{a}}$ Area $=0.5 \mathrm{~min} \times 0.5$ $\max \times 3.14$

b Volume $=$ bottom area $\times$ nest distance from the entrance
}

\begin{tabular}{|c|c|c|c|c|c|c|}
\hline Variable & $n$ & Mean & SD & Median & $25 \%$ & $75 \%$ \\
\hline \multicolumn{7}{|l|}{ Entrance } \\
\hline Least diameter $(\mathrm{cm})$ & 311 & 3.6 & 1.4 & 3.2 & 2.6 & 4.0 \\
\hline Greatest diameter $(\mathrm{cm})$ & 308 & 8.5 & 4.7 & 7.0 & 4.5 & 12.0 \\
\hline Area $\left(\mathrm{cm}^{2}\right)^{\mathrm{a}}$ & 307 & 23.7 & 16.6 & 20.3 & 11.8 & 31.4 \\
\hline \multicolumn{7}{|l|}{ Hole bottom } \\
\hline Least diameter $(\mathrm{cm})$ & 299 & 14.7 & 4.9 & 14.0 & 11.0 & 18.0 \\
\hline Greatest diameter $(\mathrm{cm})$ & 299 & 18.3 & 5.9 & 17.0 & 14.0 & 21.0 \\
\hline Area $\left(\mathrm{cm}^{2}\right)^{\mathrm{a}}$ & 299 & 228.6 & 157.7 & 183.7 & 131.9 & 282.6 \\
\hline Nest distance from entrance $(\mathrm{cm})$ & 293 & 20.7 & 10.2 & 19.0 & 14.0 & 25.0 \\
\hline 'Safety distance' (cm) & 305 & 25.7 & 8.9 & 24.0 & 20.0 & 29.0 \\
\hline Hole depth $(\mathrm{cm})$ & 180 & 33.0 & 13.8 & 30.0 & 24.0 & 39.0 \\
\hline Hole volume $\left(\mathrm{cm}^{3}\right)^{\mathrm{b}}$ & 284 & 4,777 & 5,447 & 3,370 & 2,268 & 5,785 \\
\hline
\end{tabular}


(Table 1). Most nests were within $30 \mathrm{~cm}$ of the opening (9\%<10 cm, $48 \%$ from 10 to $20 \mathrm{~cm}$, and $30 \%$ from 21 to $30 \mathrm{~cm})$, with only $13 \%(n=293)$ further than this. Nests deeper than $47 \mathrm{~cm}$ were situated in cavities with additional apertures (slits) below the opening. The nest distance from the opening increased with entrance size $\left(r_{\mathrm{S}}=0.29, P<0.001, n=289\right)$.

The 'safety' distance (measured to the centre of the nest from the external edge of the cavity entrance) ranged from 10 to $69 \mathrm{~cm}$, and was usually $5 \mathrm{~cm}$ greater than the standard nest distance (Table 1). In a majority of cavities (71\%, $n=305)$ the 'safety' distance was between 17 and $30 \mathrm{~cm}$; it strongly depended on the nest distance from the opening ( $\left.r_{\mathrm{S}}=0.83, P<0.001, n=292\right)$ and, to a lesser degree, on the cavity bottom area $\left(r_{\mathrm{S}}=0.16, P=0.006, n=290\right)$.

Nest-cavity dimensions varied among tree species (Fig. 4). Cavities in hornbeam were usually deepest and the nests were placed furthest from the entrance. In lime and hornbeam, the median entrance area was the greatest, but cavities in maple and ash usually had the largest bottom area (Fig. 4).

Cavities in limbs and trunks were of similar dimensions, with the exception of the opening shape which was more rounded in limbs; the greatest entrance diameter was shorter (median $5.6 \mathrm{~cm}, n=34$ ) in limbs than in trunks (median $7.5 \mathrm{~cm}, n=269$; Mann-Whitney test, $Z=2.4$, $P=0.017)$.
In 'knotholes', which often had round openings, the entrance area was smaller (median $11.0 \mathrm{~cm}^{2}, n=65$ ) than in other cavities (median $25.5 \mathrm{~cm}^{2}, n=186$; MannWhitney test, $Z=7.8, P<0.001)$. Consequently, Great Tits located their nests closer to the entrance in 'knotholes' (median $18.0 \mathrm{~cm}, n=59$ ) than in other cavities (median $22.0 \mathrm{~cm}, \quad n=180$; Mann-Whitney test, $\quad Z=2.3$, $P=0.023)$. However, because the median bottom area $\left(236 \mathrm{~cm}^{2}, n=62\right)$ was greater in 'knotholes' than other cavities $\left(176 \mathrm{~cm}^{2}, n=182\right.$, Mann-Whitney test, $Z=2.8$, $P=0.006)$, the median 'safety' distance remained similar in both types of cavities ( 23 and $25 \mathrm{~cm}$, respectively).

The dimensions of woodpecker-made cavities differed significantly from those which were non-excavated, having rounder, smaller openings (median entrance area 14 vs. $21 \mathrm{~cm}^{2}$ in non-excavated), were shallower (median cavity depth 23 vs. $31 \mathrm{~cm}$ ) and with shorter nest- and 'safety' distances (medians, respectively, 14 and 22 vs. 20 and $24 \mathrm{~cm}$; Mann-Whitney test, $Z>2.1, P<0.04, n=12-17$ vs. $n=163-284$ ).

\section{Discussion}

Great Tits breeding in oak-lime-hornbeam, riverine and mixed-coniferous forests used cavities located in different sets of tree species, and in this respect behaved in a similar
Fig. 4 Dimensions of Great Tit nest cavities in relation to tree species. Shown are medians (black squares), 25-75\% percentiles (grey rectangles), sample sizes given in parentheses. All dimensions varied between tree species (Kruskal-Wallis median test, $\chi^{2}=17.9-25.9, d f=5$, $P<0.001)$
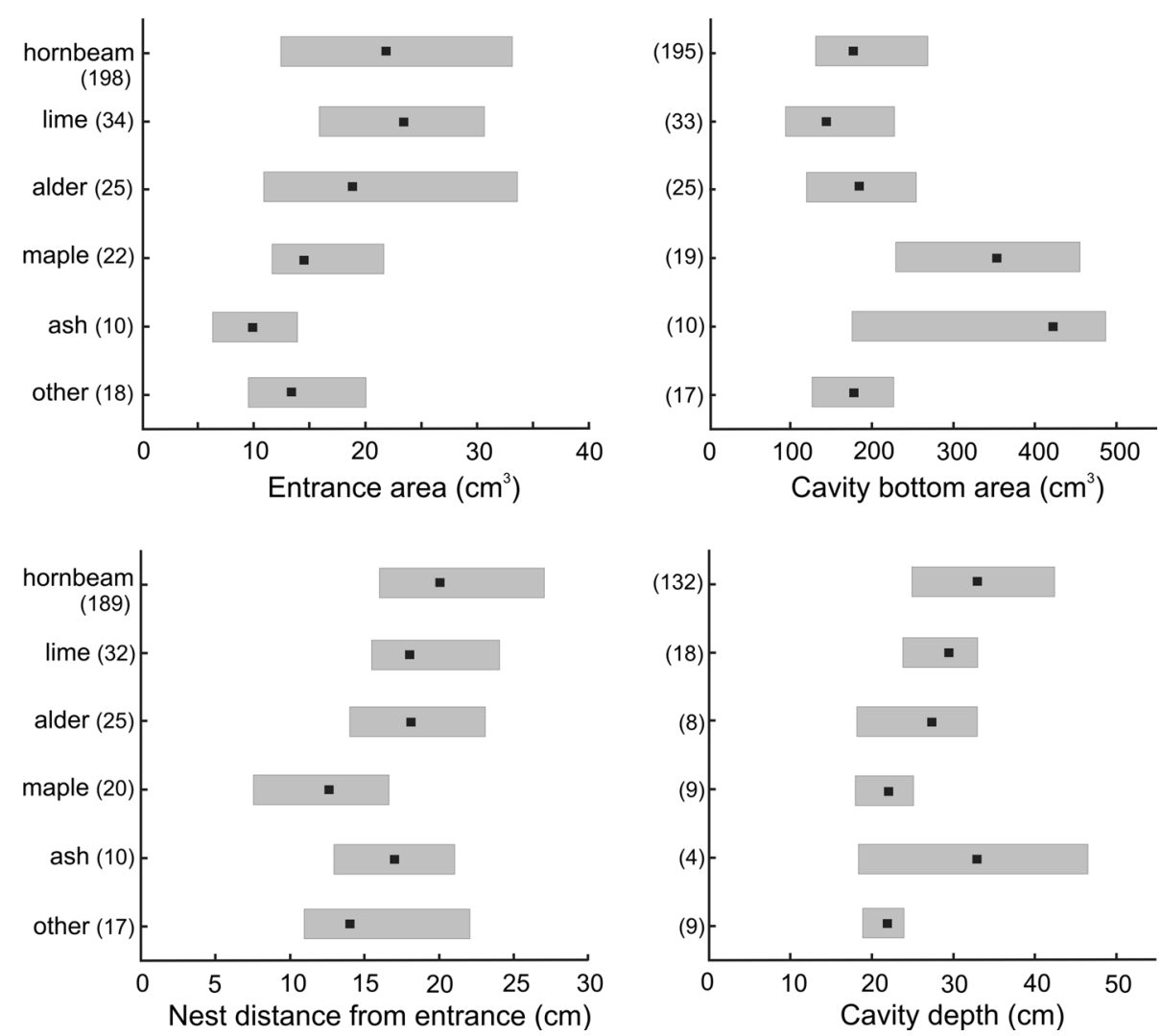
way to other non-excavating cavity-nesting species studied in BNP (Wesołowski 1989, 1996; Czeszczewik and Walankiewicz 2003; Wesołowski and Rowiński 2004, 2012; Walankiewicz et al. 2007). Preference for hornbeam and avoidance of lime and spruce in oak-lime-hornbeam habitat could suggest selection for tree species, but most probably it was explained by varying availability of suitable cavities in different tree species. The birds apparently looked for cavities with the required qualities, and if some trees provided disproportionately more of such places, they used them more often than expected. This could also explain the more frequent occupation of thicker trees, as only such trees could harbour the spacious cavities used by Great Tits. This assumption is supported by observations from other regions, where different tree species were utilised by nesting Great Tits: mainly oak in England (East and Perrins 1988) and Moscow (Morozov 2009), whitespire birch Betula platyphylla in Mongolia (Bai et al. 2005), and rowan Sorbus aucuparia or aspen P. tremula in Sweden (Sandström 1992; Carlson et al. 1998). In these studies, nest trees were also thick, with a mean diameter at breast height comparable to that in BNP (mean $47 \mathrm{~cm}$ ), with $31 \mathrm{~cm}$ in Estonia (Remm et al. 2006), $35 \mathrm{~cm}$ in Mongolia (Bai et al. 2005), $36 \mathrm{~cm}$ in Catalonia (Camprodon et al. 2008), $43 \mathrm{~cm}$ in Sweden (Sandström 1992; Carlson et al. 1998), and ca. $80 \mathrm{~cm}$ in England (East and Perrins 1988).

In 2008-2011, most Great Tits nested up to $12 \mathrm{~m}$ above the ground (mean $8.9 \mathrm{~m}$ ). This was much higher than in other studies in which the nests were placed mostly 2.3-6.5 $\mathrm{m}$ above the ground (Online Resource 6). Only in Moscow's urban woods, where $16 \%$ of Great Tit nests were located above $15 \mathrm{~m}$ (Morozov 2009), did the cavity height seem to be similar.

In comparison with other non-excavating hole-breeders in BNP, Great Tits occupied cavities at intermediate heights, similar to Collared and Pied Flycatchers (mean $8 \mathrm{~m}$; Czeszczewik and Walankiewicz 2003; Walankiewicz et al. 2007), slightly lower than Blue Tits (mean 10.6 m; Wesołowski and Rowiński 2012), but almost twice as high as Marsh Tits (mean $5.6 \mathrm{~m}$; Wesołowski 1996), and much lower than Nuthatches (mean $14 \mathrm{~m}$; Wesołowski and Rowiński 2004), or Starlings Sturnus vulgaris (14.3 m; Wesołowski 1989). In Löhrl's (1970) experiments with nest-boxes at heights of 1.75-15 m, Great Tits did not show strong preferences, although the birds slightly more often used nest-boxes at intermediate heights of 3.5 and $7 \mathrm{~m}$. However, in van Balen et al.'s (1982) study, the birds preferentially occupied lower situated cavities (0-4 m above ground). It might be presumed that nesting at intermediate heights in BNP could be a consequence of a higher frequency of spacious cavities in appropriately thicker parts of trees at that height. However, the study of nest sites of Nuthatches in BNP (Wesołowski and Rowiński 2004) revealed that spacious cavities are also abundant higher in the trees, and so could be used by Great Tits, too. Breeding in the lowest cavities may be risky due to heavy predation pressure (e.g. Nilsson 1984; Albano 1992; Broughton et al. 2011), but using the highest situated cavities may also be dangerous (Wesołowski and Rowiński 2012). Therefore, nesting at intermediate heights may, presumably, give a selective advantage to Great Tits.

Great Tits avoided nesting in dead wood (5\% of cavities in a dead limb or trunk), or in woodpecker-made cavities $(6 \%)$. In this respect, the birds' behaviour was identical to most non-excavating hole-breeders in BNP (reviewed in Wesołowski 2007b). Rare occupation of woodpecker-made cavities in dead wood by Great Tits was also recorded in England (East and Perrins 1988), Mongolia (Bai et al. 2005), and Moscow, although in the latter case many nests were located in dead parts of oak (Morozov 2009). Observations from BNP (Wesołowski 2002; Wesołowski and Rowiński 2012) and other areas (e.g. Ludescher 1973; Alatalo et al. 1990; Albano 1992; Christman and Dhondt 1997) indicate that nesting in dead wood and/or woodpecker-made cavities may be dangerous, as such places are easily accessible to, e.g., Great Spotted Woodpeckers Dendrocopos major and pine martens Martes martes, which are major predators of cavity-nesting species (reviewed in Glutz von Blotzheim and Bauer 1993, Broughton et al. 2011). Therefore, avoiding holes excavated by woodpeckers and/or with dead walls by Great Tits can be important for their successful reproduction.

In BNP, the median least entrance diameter in Great Tit cavities $(3.2 \mathrm{~cm})$ was similar to that of Pied Flycatchers $(3.5 \mathrm{~cm})$, but greater than for Blue and Marsh Tit cavities ( 2.5 and $3 \mathrm{~cm}$, respectively), and much smaller than for Collared Flycatcher cavities $(5 \mathrm{~cm})$. In comparison to other areas, the average least diameter of Great Tit cavities in BNP was one of the smallest recorded for this species (Online Resource 6). The absolute minimum of $2 \mathrm{~cm}$, found in BNP and the Netherlands (van Balen et al. 1982), probably corresponded to the minimum entrance width that birds could pass through. Smaller entrance diameters (1.6 and $1.8 \mathrm{~cm}$ ) were only reported in cavities used by Blue and Marsh Tits (Nilsson 1984; Wesołowski 1996; Wesołowski and Rowiński 2012), much smaller species than the Great Tit (Glutz von Blotzheim and Bauer 1993).

In Löhrl's (1977) experiments, Great Tits did not show a preference for breeding in nest-boxes with a particular entrance diameter, but, in this study, the size varied between 3 and $4 \mathrm{~cm}$, which corresponded to the least entrance diameter recorded in the majority of Great Tit cavities in BNP $(25-75 \%$ quartiles $=2.6-4 \mathrm{~cm})$. Nevertheless, Great Tits in BNP generally seemed to avoid breeding in cavities with very wide entrances, and, like the majority of other 
non-excavating hole-breeders (Wesołowski 1996; Czeszczewik and Walankiewicz 2003; Walankiewicz et al. 2007; Wesołowski and Rowiński 2012), they often occupied cavities with rather narrow and elongated, slit shape entrances. This has also been observed in other areas, where Great Tits used cavities with openings almost twice as long as wide (Online Resource 6). Preferential use of cavities with narrower openings by Great Tits in the Netherlands was interpreted as avoidance of inter-specific competition for nesting sites (van Balen et al. 1982). However, this could not be important in the primeval forest of BNP, where competition is a minor problem, and avoiding predation is the primary issue (e.g. Tomiałojć et al. 1984; Walankiewicz 1991; Walankiewicz and Mitrus 1997; Wesołowski 2003; reviewed in Wesołowski 2007a, b). Cavities with narrow entrances prevent larger predators from entering and plundering the nests, offering advantages for the birds (Wesołowski 2002), but using cavities with smaller entrances may bring other obstacles, such as reduced nest illumination or inefficient air ventilation (Wesołowski and Maziarz 2012; Maziarz and Wesołowski 2013, 2014). Selecting cavities with very elongated entrances, which have a larger entrance area than circular openings, may help to alleviate these problems.

Nesting in cavities with larger entrance area may also allow Great Tits to nest further from the opening, as with other non-excavators in BNP (Wesołowski 1996; Wesołowski and Rowiński 2012; Maziarz and Wesołowski 2014). The nest distance from the entrance in Great Tit cavities was greater than that reported from other areas (Nilsson 1984; East and Perrins 1988; Sandström 1992; Carlson et al. 1998; Remm et al. 2006), and was also greater than in other non-excavating cavity-nesting species studied in BNP (Fig. 5). According to van Balen et al. (1982), Great Tits' nest-site choice was rarely affected by cavity depth, but Löhrl (1986) suggested the opposite. Great Tits, having an opportunity to nest in 9-,

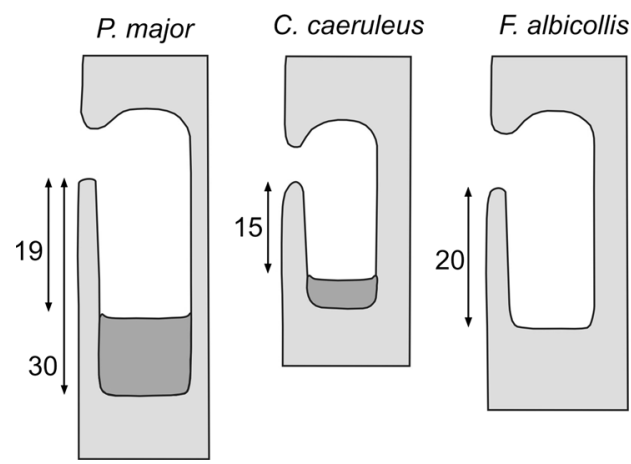

Fig. 5 Comparison of tree-cavities used by Great Tits and other nonexcavating hole-breeders in BNP. Shown are median dimensions $(\mathrm{cm})$; Flycatchers - the cavity depth measured after the nest was removed (Czeszczewik and Walankiewicz 2003; Walankiewicz et al.
14- and 19-cm-deep nest-boxes, most frequently occupied the deepest ones. Yet, the nest-boxes used in Löhrl's (1986) experiment were shallower than Great Tit cavities in BNP (median $30 \mathrm{~cm}$ ). By selecting deep cavities, the birds could adjust the thickness of the nest layer to prevent nest-soaking (Wesołowski et al. 2002) and be more flexible in adjusting the nest distance from the entrance of a particular size. This way, most Great Tits in BNP could reduce the risk of predation by maintaining a 'safety' distance of 20-29 cm (25-75\% quartiles), i.e. out of the reach of larger predators which were unable to enter the cavity (Wesołowski 2002).

In BNP, the median bottom area of Great Tit cavities was $184 \mathrm{~cm}^{2}$, larger than cavities occupied by Blue $\left(95 \mathrm{~cm}^{2}\right)$ and Marsh Tits $\left(73 \mathrm{~cm}^{2}\right)$, or Collared $\left(79 \mathrm{~cm}^{2}\right)$ and Pied Flycatchers $\left(102 \mathrm{~cm}^{2}\right)$, but smaller than Nuthatch cavities (290 $\mathrm{cm}^{2}$; Fig. 5). As spacious cavities can only exist in appropriately thicker parts of trees, the mean girth of the trunks or limbs containing Great Tit breeding cavities varied from other non-excavators in the same way (Wesołowski 1996; Czeszczewik and Walankiewicz 2003; Wesołowski and Rowiński 2004, 2012; Walankiewicz et al. 2007). The mean bottom area of Great Tit cavities in other areas was smaller than in BNP, except for Sweden (Online Resource 6).

The evidence for Great Tits preferring to breed in relatively large cavities comes from several studies. Henze (1964) found that nest-boxes with a bottom area of $182 \mathrm{~cm}^{2}$ were preferred to $132 \mathrm{~cm}^{2}$. van Balen et al. (1982) also showed that, when the effect of competition was excluded, Great Tits preferred tree cavities with larger bottom diameters. In Germany, Winkel (1985) remarked that Great Tits almost exclusively occupied nest-boxes with bottom dimensions of $14 \times 18.5 \mathrm{~cm}$, avoiding those of $12 \times 12.5 \mathrm{~cm}$, and Löhrl (1986) reported the highest occupation rate in nest-boxes with the largest bottom diameter (20 cm over 11.5 and $14 \mathrm{~cm}$ ). Only Nilsson (1975)

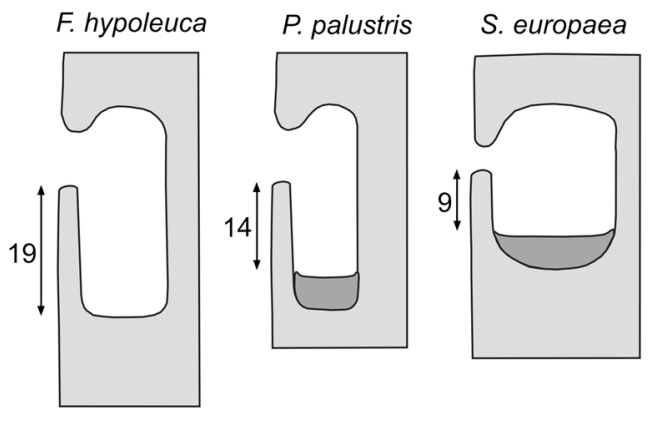

2007), while for Nuthatch, Marsh and Blue Tit only the depth to the nest is given (Wesołowski 1996; Wesołowski and Rowiński 2004, 2012) 
recorded a higher frequency of occupying medium-sized nest-boxes (bottom area $87 \mathrm{~cm}^{2}$ ) rather than the largest $\left(104 \mathrm{~cm}^{2}\right)$.

Nesting in larger cavities might be advantageous for Great Tits due to better insulation (Löhrl 1986), as birds can build proportionally larger nests to more efficiently insulate eggs or nestlings, and protect nest contents against soaking (Wesołowski et al. 2002). In these larger cavities, the risk of hyperthermia, ammonia concentration, trampling of young, disease transmission or predation risk could also be reduced (e.g. Löhrl 1973, 1986; Slagsvold 1989; Erbelding-Denk and Trillmich 1990; Wiebe and Swift 2001). However, the nest-boxes which are deployed and used extensively in long-running studies of Great Tit breeding ecology (reviewed in Lambrechts et al. 2010), have much smaller internal dimensions than those recorded in natural cavities in BNP and elsewhere (Online Resource 6). This may raise serious concerns, as offering nest-sites of smaller size to natural nest-sites of Great Tits may have selective consequences for the birds and affect the results of ecological investigations (Lambrechts et al. 2010).

In summary, this is the first thorough, long-term study presenting a detailed overview of the natural nest-sites of Great Tits. The recorded pattern of the nest-site selection largely confirms results from the preliminary study of this species in BNP (Wesołowski 1989), indicating that these aspects of Great Tit behaviour remained unchanged over almost 40 years, and that the results are representative for this area. Although Great Tits in BNP have access to abundant tree cavities of diverse locations and dimensions, they typically occupy non-excavated, deep and spacious cavities with elongated and rather narrow openings, placed at intermediate heights $(5-12 \mathrm{~m})$ in living trunks. While showing a large degree of plasticity for nesting in artificial locations in modified habitats (see "Introduction"), in primeval conditions Great Tits are conservative in their choice of nest-sites. The properties of cavities occupied by Great Tits in the primeval forest of BNP are similar to natural nest sites of this species in other parts of Europe. This suggests some core nest-site preferences of Great Tits which have probably evolved in response to selective factors, such as, e.g. predation pressure, flooding, sufficient nest illumination, and/or efficient air ventilation. Additionally, our results highlight that the dimensions of nest-boxes widely used in studies of Great Tits in Europe differ significantly from those of natural nest-sites. The wider implications of this discrepancy should be considered.

Acknowledgments $\mathrm{We}$ are very grateful to $\mathrm{P}$. Białomyzy, M. Czuchra and P. Rowiński for their help in the field work, J.P. Cygan for the photographs, and Arie van Noordwijk and an anonymous reviewer for improvements to the manuscript. We also thank the Białowieża National Park administration for kind co-operation. The presented data constitute a part of unpublished PhD thesis (Maziarz 2012). Research was supported by the internal grants from the Faculty of Biological Sciences, Wrocław University (M.M., T.W., M.Ch.), and by EU Human Capital Programme (M.M.). The study complied with the current Polish Law and was permitted by the Ministry of the Environment.

Open Access This article is distributed under the terms of the Creative Commons Attribution License which permits any use, distribution, and reproduction in any medium, provided the original author(s) and the source are credited.

\section{References}

Alatalo R, Carlson A, Lundberg A (1990) Polygyny and breeding success of pied flycatchers nesting in natural cavities. In: Blondel J, Gosler A, Lebreton JD, McCleery R (eds) Population biology of passerine birds. Springer, Berlin, pp 323-330

Albano DJ (1992) Nesting mortality of Carolina chickadees breeding in natural cavities. Condor 94:371-382

Bai M-L, Wichmann F, Mühlenberg M (2005) Nest-site characteristics of hole-nesting birds in a primeval boreal forest of Mongolia. Acta Ornithol 40:1-14

Bobiec A (2002) Living stands and dead wood in the Białowieża forest: suggestions for restoration management. For Ecol Manag 165:125-140

Booij CJH (1977) De broedresultaten van holendroeders in natuurlijke holtes. Internal Rept. 14, Innstituut von Oecologish Onderzoek, Arnhem, The Netherlands

Broughton RK, Hill RA, Bellamy PE, Hinsley SA (2011) Nest-sites, breeding failure, and causes of non-breeding in a population of British marsh tits Poecile palustris. Bird Study 58:229-237

Camprodon J, Salvanyà J, Soler-Zurita J (2008) The abundance and suitability of tree cavities and their impact on hole-nesting bird populations in beech forests of NE Iberian Peninsula. Acta Ornithol 43:17-31

Carlson A, Sandström U, Olsson K (1998) Availability and use of natural tree holes by cavity nesting birds in a Swedish deciduous forest. Ardea 86:109-112

Christman BJ, Dhondt AA (1997) Nest predation in black-capped chickadees: how safe are cavity nests? Auk 114:769-773

Czeszczewik D, Walankiewicz W (2003) Natural nest sites of the pied flycatcher Ficedula hypoleuca in a primeval forest. Ardea 91:221-230

East ML, Perrins CM (1988) The effect of nestboxes on breeding populations of birds in broadleaved temperate woodlands. Ibis 130:393-401

Edington JM, Edington MA (1972) Spatial patterns and habitat partition in the breeding birds of an upland wood. J Anim Ecol 41:331-357

Erbelding-Denk C, Trillmich F (1990) Nestbox climate and its effects on starling (Sturnus vulgaris) nestlings. J Ornithol 131:73-84 (in German)

Gibb J (1950) The breeding biology of the great and blue titmice. Ibis 92:507-539

Glutz von Blotzheim U, Bauer KM (1993) Handbuch der Vögel Mitteleuropas, vol 13. Aula, Wiesbaden

Gosler A (1993) The great tit. Hamlyn, London

Henze J (1964) Welche Brutraummasze benötigen die höhlenbrütenden Meisenarten? Vogelwelt 85:136-150

Kluijver HN (1951) The population ecology of the great tit, Parus $m$. major L. Ardea 39:1-135

Lack D (1965) Evolutionary ecology. J Appl Ecol 2:247-255 
Lambrechts MM, Adriaensen F, Ardia DR et al (2010) The design of artificial nestboxes for the study of secondary hole-nesting birds: a review of methodological inconsistencies and potential biases. Acta Ornithol 45:1-26

Löhrl H (1970) Unterschiedliche Bruthöhlenansprüche von Meisenarten und Kleibern als Beitrag zum Nischenproblem. Verh dt zool Ges 64:314-317

Löhrl H (1973) Influence of nest-box size on clutch size of the great tit (Parus major). J Ornithol 114:339-347 (in German)

Löhrl H (1977) Ecological and ethological adaptations in hole-nesting birds. Vogelwarte 29:92-101 (in German)

Löhrl H (1986) Experiments on nest-site selection in great tit, Parus major. J Ornithol 127:51-59 (in German)

Ludescher FB (1973) The marsh tit (Parus palustris) and the willow tit (Parus montanus) as sympatric sibling-species. J Ornithol 114:3-56 (in German)

Mänd R, Tilgar V, Lõhmus A, Leivits A (2005) Providing nest boxes for hole-nesting birds - does habitat matter? Biodivers Conserv 14:1823-1840

Maziarz M (2012) The nest sites' characteristic and breeding success of great tit Parus major in primeval conditions (Białowieża National Park). PhD thesis, University of Wrocław (in Polish, English summary)

Maziarz M, Wesołowski T (2013) Microclimate of tree cavities used by great tits (Parus major) in a primeval forest. Avian Biol Res 6:47-56

Maziarz M, Wesołowski T (2014) Does darkness limit the use of tree cavities for nesting by birds? J Ornithol 155:793-799

Monrós JS, Gómez J, Encabo SI, Bradt S, Barba E, Gil-Delgado JA (1999) Open nesting in great tits Parus major. Ardeola 46:89-91

Morozov NS (2009) A city as an object for synecological studies: a search for density compensation among birds breeding in urban woodlands. In: Golovatch SI, Makarova OL, Babenko AB, Penev LD (eds) Species and communities in extreme environments. Pensoft, Sofia, pp 459-520

Newton I (1998) Population limitation in birds. Academic, London

Niechoda T, Korbel J (2011) Puszczańskie olbrzymy. Towarzystwo Ochrony Krajobrazu, Białowieża

Nilsson SG (1975) Kullstorlek och häckningsframgång i holkar och naturliga hål. Vår Fågelvärld 34:207-211

Nilsson SG (1984) The evolution of nest-site selection among holenesting birds: the importance of nest predation and competition. Ornis Scand 15:167-175

Perrins CM (1979) British tits. Collins, London

Remm J, Lõhmus A, Remm K (2006) Tree cavities in riverine forests: what determines their occurrence and use by hole-nesting passerines? For Ecol Manag 221:267-277

Sandström U (1992) Cavities in trees: their occurrence, formation and importance for hole-nesting birds in relation to silvicultural practise. Rapport 23, Swedish University of Agricultural Sciences, Uppsala

Slagsvold T (1989) Experiments on clutch size and nest size in passerine birds. Oecologia 80:297-302

StatSoft, Inc. (2011) STATISTICA (data analysis software system), version 10. http://www.statsoft.com

Tomiałojć L, Wesołowski T (2004) Diversity of the Białowieża forest avifauna in space and time. J Ornithol 145:81-92

Tomiałojć L, Wesołowski T, Walankiewicz W (1984) Breeding bird community of a primaeval temperate forest (Białowieża National Park, Poland). Acta Ornithol 20:241-310

van Balen JH (1973) A comparative study of the breeding ecology of the great tit Parus major in different habitats. Ardea 61:1-93 van Balen JH, Booy CJH, van Franeker JA, Osieck ER (1982) Studies on hole-nesting birds in natural nest sites. 1. Availability and occupation of natural nest sites. Ardea 70:1-24

Walankiewicz W (1991) Do secondary cavity-nesting birds suffer more from competition for cavities or from predation in a primeval deciduous forest? Nat Area J 11:203-212

Walankiewicz W, Mitrus C (1997) How nest-box data have led to erroneous generalizations: the case of the competition between great tit Parus major and Ficedula flycatchers. Acta Ornithol 32:209-212

Walankiewicz W, Czeszczewik D, Mitrus C (2007) Natural nest sites of the collared flycatcher Ficedula albicollis in lime-hornbeamoak stands of a primeval forest. Ornis Fenn 84:155-162

Wesołowski T (1989) Nest-sites of hole-nesters in a primaeval temperate forest (Białowieża National Park, Poland). Acta Ornithol 25:321-351

Wesołowski T (1995) The loss of avian cavities by injury compartmentalization in a primaeval European forest. Condor 97:256-257

Wesołowski T (1996) Natural nest sites of marsh tit (Parus palustris) in a primaeval forest (Białowieża National Park, Poland). Die Vogelwarte 38:235-249

Wesołowski T (2001) Ground checks-an efficient and reliable method to monitor holes' fate. Ornis Fenn 78:193-197

Wesołowski T (2002) Anti-predator adaptations in nesting marsh tits Parus palustris: the role of nest-site security. Ibis 144:593-601

Wesołowski T (2003) Bird community dynamics in a primaeval forest-is interspecific competition important? Ornis Hung 12-13:51-62

Wesołowski T (2007a) Primeval conditions-what can we learn from them? Ibis 149(Suppl 2):64-77

Wesołowski T (2007b) Lessons from long-term hole-nester studies in a primeval temperate forest. J Ornithol 148(Suppl 2):S395-S405

Wesołowski T (2011) "Lifespan" of woodpecker-made holes in a primeval temperate forest: a thirty year study. For Ecol Manag 262:1846-1852

Wesołowski T (2012) "Lifespan" of non-excavated holes in a primeval temperate forest: a 30 year study. Biol Conserv 153:118-126

Wesołowski T, Maziarz M (2012) Dark tree cavities-a challenge for hole nesting birds? J Avian Biol 43:454-460

Wesołowski T, Rowiński P (2004) Breeding behaviour of nuthatch Sitta europaea in relation to natural hole attributes in a primeval forest. Bird Study 51:143-155

Wesołowski T, Rowiński P (2012) The breeding performance of blue tits Cyanistes caeruleus in relation to the attributes of natural holes in a primeval forest. Bird Study 59:437-448

Wesołowski T, Czeszczewik D, Rowiński P, Walankiewicz W (2002) Nest soaking in natural holes-a serious cause of breeding failure? Ornis Fenn 79:132-138

Wesołowski T, Rowiński P, Mitrus C, Czeszczewik D (2006) Breeding bird community of a primeval temperate forest (Białowieża National Park, Poland) at the beginning of the 21st century. Acta Ornithol 41:55-70

Wesołowski T, Mitrus C, Czeszczewik D, Rowiński P (2010) Breeding bird dynamics in a primeval temperate forest over thirty five years: variation and stability in the changing world. Acta Ornithol 45:209-232

Wiebe KL, Swift TL (2001) Clutch size relative to tree cavity size in northern flickers. J Avian Biol 32:167-173

Winkel W (1985) On the first occupation of different-sized nestboxes by tit mice and other hole breeders in a study area. Die Vogelwelt 106:256-264 (in German) 